\title{
Promoting multiculturalism: Teachers' English proficiency and multicultural education in Indonesia
}

\author{
Chuzaimah Dahlan Diem ${ }^{1}$ and Umar Abdullah ${ }^{2}$ \\ ${ }^{1}$ Department of Language and Arts Education, Faculty of Teacher Training and Education, Sriwijaya University, \\ Jalan Palembang-Prabumulih, Km.32 Indralaya Kabupaten Ogan Ilir, Sumatra Selatan 30662, Indonesia \\ ${ }^{2}$ Department of English Education, Faculty of Tarbiyah and Teacher Training, UIN Raden Fatah Palembang, \\ Jl. Prof. K.H. Zainal Abidin Fikri KM. 3,5 Palembang Sumatra Selatan, 30126, Indonesia
}

\begin{tabular}{|c|c|}
\hline $\begin{array}{l}\text { ABSTRACT } \\
\text { Greater disparities and inadequacies of English proficie } \\
\text { process for EFL teachers of different cultural backgro } \\
\text { condition of } 104 \text { English as a Foreign Language (EFL) } \\
\text { Sumatra in relation to such variables as education lev } \\
\text { assignment level, and gender. Using English test scores } \\
\text { and in-service), EL, gender, multicultural education } \\
\text { teachers' EP is described. This study reveals that EL } \\
\text { predictor of their cultural knowledge and experience, su } \\
\text { curriculum instruction, general sensitivity, and cult } \\
\text { teaching at higher levels of education appear to be better } \\
\text { and in-service teachers are also better than pre-service } \\
\text { Although there is no difference in gender in their EP as } \\
\text { personal development are significantly correlated. The } \\
\text { to be proficient in English and culturally developed wit } \\
\text { master's degree in addition to having an in-service statu }\end{array}$ & $\begin{array}{l}\text { may influence the educational } \\
\text { s study aims at describing the } \\
\text { EP in the Southern Region of } \\
\text { ultural backgrounds, teaching } \\
\text { rs' teaching status (pre-service } \\
\text { ire, and teaching assignment, } \\
\text { EP and also becomes the best } \\
\text { sonal development, leadership, } \\
\text { reness. Furthermore, teachers } \\
\text { those teaching at lower levels, } \\
\text { n their teaching responsibility. } \\
\text { emales' EP, listening skill, and } \\
\text { n of the findings indicates that } \\
\text {, teachers must have at least a } \\
\text { ing employment. }\end{array}$ \\
\hline Keywords: EFL teachers; English proficiency; multicul & nulticultural education \\
\hline $\begin{array}{l}\text { First Received: } \\
15 \text { February } 2020 \\
\text { Final Proof Received: } \\
21 \text { May } 2020\end{array}$ & $\begin{array}{l}\text { Accepted: } \\
\text { 30 April } 2020 \\
\text { Published: } \\
\text { 31 May 2020 }\end{array}$ \\
\hline $\begin{array}{l}\text { How to cite (in APA style): } \\
\text { Diem, C. D. \& Abdullah, U. (2020). Promoting multicul } \\
\text { and multicultural education in Indonesia. Indonesi } \\
\text { 10(1), 46-58. https://doi.org/10.17509/ijal.v10i1.2 }\end{array}$ & $\begin{array}{l}\text { Teachers' English proficiency } \\
\text { l of Applied Linguistics, }\end{array}$ \\
\hline
\end{tabular}

\section{INTRODUCTION}

In this global era, English literacy is vital and thus must be mastered by every citizen in the world, including EFL teachers. In addition to reading and writing, literacy is a term used to refer to being knowledgeable and well-informed (Livingstone et al., 2005). Thus, literacy has been associated with not only linguistics literacy but also other types of literacy such as, “... media literacy, visual literacy, [and] functional literacy..." (Hill, 2006 - 2008, p. 3). The quick advancement of information and communication technology (ICT) has altered civilization and the notion of literacy has shaped new aspects of human life, including the ownership of multicultural sensitivity and awareness in addition to internet literacy which is the basic need of this global era. The newly emerging concept of literacy, which refers to the individual's skill to play his/her role competently in a global society, should be possessed by every person to be able to thrive and actively participate in today's society (Cloud et al., 2009; Jones-Kavalier \& Flannigan, 2006; United Nations, 2013). According to Graddol (2000), to be fully literate in this era EFL teachers must fulfill the international standards by obtaining at least a paperbased TOEFL score of 550 to 600 (The George

\footnotetext{
* Corresponding Author

Email: umarfillah@yahoo.com
} 
Washington University, 2013) or between 550 and 587 (Vancouver English Centre, 2013). In order to be knowledgeable and well-informed, EFL teachers should also be literate in the Internet, possessing the necessary ability to work with internet services (Livingstone et al., 2005). Unfortunately, the 2013 survey by the Internet Service Provider Association in Indonesia (the English term for Asosiasi Penyelenggara Jasa Internet Indonesia - APJII) showed that only 28 percent of the total Indonesian population was literate in the internet, which is still far from fulfilling the expected percentage of being globally literate by 2015 (APJII, 2014).

The lack of literacy is assumed to be partly related to the inadequacy of English proficiency of Indonesian English language teachers. The results of teachers' English competency tests carried out in South Sumatra (Lembaga Penjaminan Mutu Pendidikan Sumatra Selatan [LPMP], 2012) showed that only 10.54 per cent of 24,808 certified teachers from 15 regencies had achieved the average high scores, i.e. 50-75 or above (on a 100-scale), which is still far below the standards mandated by the Indonesian Act of the National Education System No.14/2005 article 20 and the Government Regulation No.74/2009, chapter II Part 1 article 3. The law and regulation prescribe that every teacher should take advantage of ICT for the purpose of English education and having awareness or sensitivity of multi-cultures. This prescription is manifested in the revision of the 2013 curriculum structure that integrates ICT in all subjects taught and matches the use of it with the demand of the $21^{\text {st }}$ century era of globalization (Kemendikbud, 2013). In other words, both student teachers and practicing teachers have to be literate in English and technology to ensure their students possess the quality of $21^{\text {st }}$ century education to prepare them to thrive in today's global and multicultural society.

Recognition of the pluralistic nature of populations within geographic boundaries calls for education to build understanding and develop the desirability of diversity. Awareness of this need through the long history of nations and people has led to the current status of multicultural education (ME). Within ME context, the presence of English as a universal language, especially when it is used in an argument, sounds elegant in one culture but may not so in other cultures. Such recognition subsequently brings awareness to foreign language teaching scholars that language is closely linked to culture.

While the importance of English for teacher's academic success and professional development has been extensively discussed in literature, still little is known about the relationship between English proficiency and multicultural education (ME), especially in Indonesian context. The concept of ME is much more than knowledge and understanding; it instead pertains to how we respect human beings and treat them equally whatever their background is. The relationship between English and multi-cultures, especially in the teaching sector, is a significant topic to investigate. This study, therefore, aims to determine whether student teachers and practicing teachers' English proficiency is significantly related to their knowledge of ME.

\section{English in the $21^{\text {st }}$ Century and multicultural society}

Most of research and information is available on the internet, and English is the dominant language to access the information (British Council, 2011; EF EPI, 2012). EFL teachers often lack the skill necessary to help them effectively and efficiently access, comprehend, evaluate, select, and share any genres of information, which are multicultural, because of their low quality of English (the American Association of School Librarians [AASL], 2007; the National Council of Teachers of English [NCTE], 2009). By including the language skills into the definition of new literacy, EFL pre-service and inservice teachers need to activate and upgrade their English literacy skills to enable them to retrieve information and use it for their work. Individuals with low proficiency in English will be left behind in the multicultural society, because English proficiency is needed to gain access to information in the digital era, $21^{\text {st }}$ century literacy

As part of literacy, reading is one of the language skills related to almost all processes of learning. One's good reading ability would help him/her learn other subjects. Through reading, individuals learn new information and are capable to synthesize, evaluate and interpret information for the sake of their subject matter learning. According to NCTE (2009), $21^{\text {st }}$ century citizens need to gather information from multiple sources, evaluate and apply their findings effectively, including those which contain various cultures (Geske \& Ozola, 2008). In fact, reading activity is a significant area of an individual's learning (Noor, 2011). It is a basic skill for learning, a key indicator of success in school and in life (AASL, 2007) and is a test component required in national examination in Indonesia (Sunggingwati \& Nguyen, 2013).

However, data from 2018 PISA showed that the level of reading skill level of 15-year-old Indonesian students was unsatisfactory (OECD, 2019). It ranked $72^{\text {nd }}$ out of 77 countries, with more than half of the students proficient only at or below level 1 . This rank represents serious problems in reading activity as a device to advance and extend knowledge and skills in other areas. Diem (2012) reported that EFL reading comprehension score achieved by Senior High Schools (SMA) students in South Sumatra was also below the standard. Based on gender, the mean scores of their reading achievement were respectively only 49.05 for female students and 46.67 for male students, which were below the standard score of national education. One of the main causes of this 
low score is the inability to access relevant reading resources, either offline or online provided in schools (Diem \& Novitasari, 2012).

As a universal language, English is a vital factor for academic success, global career, international communication, and obtaining academic degrees from overseas universities (Focho, 2011; Jenkins, 2006). It is the favored language of publications, online communication and technological transfer (Graddol, 2000). In Indonesia, English proficiency is a prerequisite of higher education, admission to reputable universities, getting undergraduate degrees, and applying for a job (Baker, 2003; Yahya, 2012). In Indonesian schools, English has become the first foreign language taught in elementary schools, 100 per cent displacing many other local content subjects in Palembang (Yusfadiyah, 2010). This phenomenon is in line with Dickson and Cumming's (1996) and Crystal's (2003) hypothesis that English is the first preferred foreign language to be taught at school even in countries whose language is other than English.

English has been the first requirement for employees and economic well-being in human life (Coleman, 2010), making it vital for many people to learn if they want to succeed to compete in the global workforce. Study by Global English in 2010 revealed that 55 per cent of 26,000 EFL background employees used English as a routine medium of communication at work (EF EPI, 2012). Individuals with low English proficiency will fail to keep up with their counterparts from other countries in the $21^{\text {st }}$ century society, which is multicultural by nature (see Bjorn, Stein, \& Fathul, 2005). As evidence, more than 35 per cent of research publications were coauthored by researchers from different nationalities; In addition, the manuscripts submitted by candidates with low quality of writing in English regardless their relevant qualifications are mostly rejected (Yahya, 2012).

\section{Multiculturalism and multicultural education}

The notion of multiculturalism was initially introduced in Canada in 1971 as part of Trudeau administration program in an attempt to provide equal opportunities for the national minorities and immigrants regardless of their backgrounds, including social status, political view, and ethnicity (Fleras \& Elliott, 2002; Guo, 2011). Parekh (2000) linked multiculturalism to a blend of various cultures through culture. In a similar vein, multiculturalism is the condition when individuals with different backgrounds such as culture, language and belief, stay side by side in the same area and respect each other's differences (Colombo, 2015). Within multiculturalism, the presence of diverse social structures, identities, and cultures is considered as the driving source of change in society. Accepting diversity, cultivating unity, and making it as a routine, can be realized by practicing ME (Fowers \& Davidov, 2006). Multicultural Education identifies certain principles, values, and practices, which are arguably compatible with almost every aspect of work and life (Shannon-Baker, 2018). Therefore, Singh (1984) considers ME a vital factor in the curriculum. His study suggests that if one sees ME as an initial understanding of a blend of diverse cultures, ME could be then integrated in every curriculum (see also, Brent, 1982).

According to Vasquez and Ingle (1982), ME involves a broad concept in which the word 'culture' itself includes collective experience, employment status, ethnic heritage, linguistic background, and gender. Furthermore, ME covers an educational milieu (comfortable interaction of teachers and students) that presents a challenge of equitably educational chances for people whose ethnicity, culture, belief, and education are diverse (Campbell \& Farrell, 1985; Rohner, 1984). Therefore, Good and Brophy (1987) described the need for ME "to elicit active participation of all students in classroom activities, and [as] the attempt to get beyond mere tolerance..." (p. 410). ME prescribed that every student should be provided with equal opportunities in education unhampered by such differences as race, ethnic, language, belief, sex, culture, and social status (Banks, 2001a, 2001b; Yilmaz, 2016). Importantly, Multicultural Education should nurture students' mindfulness of their own and other's differences that make up humanity (Suzuki, 1979).

Baptiste, Jr. (1986) stated that ME affiliates itself with the nature of cultural pluralism. To internalize the concept of $\mathrm{ME}$, teachers need to understand various definitions posited by the researchers in ME field cited earlier (see Banks, 2001a, 2001b; Brent, 1982; Fowers \& Davidov, 2006; Shannon-Baker, 2018; Singh, 1984; Suzuki, 1979; Yilmaz, 2016). Although the formalization of the concept of ME is somewhat less familiar in the Indonesian educational system, by studying the definition provided by the researchers above, it is apparent that the concept of ME is valid for every nation in the world, especially for one that is multiethnic or multicultural like Indonesia, and a mixture of different ethnic groups can easily be found in big cities like Palembang.

The dearth of essential data on ethnic diversities and social behaviors has implications for national education policy and programs. However, policies seem to have been implemented with very little consideration for different ethnic and cultural groups of the nation (Suparlan \& Sigit, 1980). Due to the lack of empirical data, research in this area is important and should be carried out on Indonesian ethnic groups in Indonesia, including individuals of Chinese ancestry, Javanese, Bataknese, and Palembangnese ethnic groups. In Palembang, there are on average 40 per cent of students with Chinese ancestry attending private schools like Xaverious, Methodist, and Kusuma Bangsa, where in many, especially state schools, Muslims constitute 57 per cent of the total 
population (Source: Interviews with teachers of English and the administration of the schools involved in this study, 2014).

Banks (1986) maintains the educational profession must address some important multicultural requirements. These include the following: (1) to support sound academic standards in the education of teachers (Rodriguez, 1981); (2) to integrate the students' background and cultural context in teaching-learning process (Werner, 1979); (3) to involve teachers from different background of cultures who can reflect and address the particular concerns of various cultural groups (Chavers, 1979); and (4) to develop awareness and sensitivity regarding cultural differences among students. These needs are supported by Gollnick and Chinn (1986) who argue that Multicultural Education for teachers should promote professional competence when it comes to the needs of pluralistic society. They confirm that multicultural insight helps sensitize teachers to their routine teaching activities, getting along with ethnically and culturally diverse students. In particular, it may give English teachers knowledge and skills and understanding of the social and cultural elements of their students' upbringing and experience that contributes to the formation of particular personalities. Leading them to acknowledge and respect these distinctive characteristics is important because student teachers' and practicing teachers' understanding of differences in cultures often determines the content of the curriculum and methods of teaching.

A limited range of studies have examined different cultures in teaching-learning settings. Berliner and Cassanova (1986) suggest that culture influences reading comprehension, and Jensen (1980) offers a comprehensive summary of how cultural and ethnic differences influence performances on mental tests. Mitchelmore (1980) studied American, English and Jamaican students, while Shar and Geeslin (1980) looked at American and Swiss students both of which found how significant culture-related differences are perceived and conceptualized. Yilmaz's (2016) study explored teacher candidates' perceptions of multicultural education and found that their positive attitudes toward ME help shape their understanding of diversity and respect for individual differences. Studying the administration of ME in a school in Medan, Indonesia, Purba et al. (2019) found that multicultural education program has improved students' tolerance of religious and ethnic differences.

Although for many years educators have been grappling with cultural pluralism, the results of Mitchell's (1985) study show that there still exists a general lack of understanding regarding the need for multicultural programs. Mitchell suggests that if educators are to achieve basic objectives of cultural pluralism, schools need to intensify their efforts dramatically. Based on the views of multicultural education proponents, Berliner (1986) clearly states that "teachers (including pre-service and in-service teachers) have no choice but to enquire into each student's unique culture and learning history to determine what instructional materials might best be used, and ... when student's cultural and life experiences are compatible, or potentially incompatible, with instruction" (p. 29).

The Midwest Race Desegregation Assistance Centre (1983) recommends certain steps to assess, plan and improve ME in schools. An initial step towards meeting these recommendations is to retrieve information from teachers regarding their self-assessment in ME. It is apparent that the need for studies that highlight the important relationship between ME understanding and perception should be done because these relate to teacher performance in English language teaching in classrooms. In this study, pre-service and in-service teachers' English proficiency was correlated with their ME.

\section{METHOD}

Greater disparities and inadequacies of English proficiency (EP) may influence the educational process for EFL teachers of different cultural backgrounds in terms of employability status (preservice and in-service), education level (undergraduate and graduate) and gender (male and female). While teachers' EP is associated with their score of the subsets, like listening, structure and written expression, and reading, Multicultural Education (ME) is indicated by its subsets, such as personal development, curriculum instruction, school leadership, community responses, general awareness, general sensitivity and expectation and responses.

The data of this study was obtained using measures of perception designed for and used with pre-service and in-service (employability or teaching status) EFL teachers. The main purpose was to see whether these teachers' English proficiency (EP) was statistically correlated to teachers' multicultural education (ME) in EFL teaching and learning processes. A secondary purpose was to test if the addition of some variables, such as education level (EL), teaching assignment that is at primary school education (PSE), junior high school education (JHSE), senior high school education (SHSE), higher education (HE) and gender (male and female) to the prediction models of each of the seven variables of ME (MEPD, MECI, MESL, MECR, MEGA, MEGS, MEER) from teachers' English proficiency (EP), results in a significant increase in the variation for ME. Therefore, particular factors required to observe the increase in explained variation and provide a parsimonious model for each of the teachers' $\mathrm{ME}$ measures were identified. Another purpose of this study was to subjectively compare the resulting 
prediction models for both types of employability status of teachers (pre-service vs.in-service).

The population of this study comprised a selected group of teachers who taught English as a foreign language (EFL) in Palembang City primary school, junior high school, senior high school, and higher education levels. Specifically, subjects chosen for the sample were pre-service and in-service teachers who have had either undergraduate or graduate degrees in English education. The teachers were asked to volunteer for this study and respond to (1) the Teacher Self-Assessment in Multicultural Education instrument, and (2) teachers' demographic data consisting of (a) education level, (b) employability status (in-service vs. pre-service), (c) teaching assignment level, and (d) gender. Teachers' English proficiency was taken from their scores of teachers' English test administered by the Faculty of Teacher Training and Education at a public university in South Sumatra during the academic year of 2014/2015.

The Teacher Self-Assessment in Multicultural Education developed by the Midwest Race Desegregation Assistance Centre, Kansas State University (1983) consists of 50 statements. Each statement has responses which can be checked in five categories: almost always - 1; frequently - 2; occasionally -3 ; almost never -4 ; and not applicable -5 . The fifty assessment statements were given to 80 school teachers assigned from every level of education in Palembang, and their responses were secured and factor analyzed.

The principal-components analysis indicated a seven-factor solution. Mean substitution was used for missing data (average for all who responded). A principal-axis analysis using a varimax rotation was then used to provide a factor structure solution. Subsequently, the seven factors or subsets were given the following designations: (a) ME: Personal Development (MEPD) - items 1 - 14; (b) ME: Curriculum Instruction (MECI) - items 15 - 25; (c) ME: School Leadership (MESL) - items 26 - 30; (d) ME: Community Relations (MECR) - items 31 - 36; (e) ME: General Awareness (MEGA) - items 37 41; (f) ME: General Sensitivity (MEGS) - items $42-$ 46; and (g) ME: Expectations and Responses (MEER) - items 47 - 50. These designations were given based on the main idea represented by the cluster of items making up each factor.

The score of the reliabilities (coefficient alphas) of the Multicultural Education variable total (ME Total) is .93 and each factor of the seven subsets of ME's Cronbach's Alpha is as follows: MEPD (.81), MECI (.82), MESL (.82), MECR (.75), MEGA (.71), MEGS (.76), and MEER (.72).

\section{RESULTS}

The following discussion will be based on the results of the data analyses concerning variables of the study.
Mean difference of pre-service and in-service teachers' English proficiency (EP) and Multicultural education (ME) based on education level (EL), teaching assignment (TA), and gender The total mean scores $(\mathrm{N}=104)$ of the teachers' EP and their ME are respectively 485.4 and 177. The summary of mean scores and level of significance between pre-service and in-service teachers' English proficiency (EP) and multicultural education (ME) based on their education level (EL) (undergraduates BA and graduates - MA), teaching assignment (TA), and gender is presented in Table 1 and Table 2.

The statistical analyses of the actual data appropriate for verifying the research questions that include the $t$-values of the main variables (English Proficiency and Multicultural Education) between both teachers' teaching status (pre-service and inservice) based on their education level, teaching assignment, and gender are shown in Table 1.

This study reveals that teachers' total English proficiency (EP) in relation to their employability or teaching status (pre-service and in-service) is significantly different in terms of their education level (t-value -4.046 with $\mathrm{p}<.000$ ) and teaching assignment although only for those who teach at senior high school $(\mathrm{p}<.04)$ and higher education $(p<.001)$. The same is true when it is partially analyzed from each sub-variable of English proficiency (Listening), especially based on both education level $(\mathrm{p}<.000)$ and teaching assignment level (but only at SHS p<.040 and HE, p<.001), and Structure is significantly different only at $\mathrm{HE}$ ( $\mathrm{p}<.008)$. However, for Reading there is no significant difference between in-service and preservice teachers based on education level, teaching assignment level, or gender.

In terms of $\mathrm{ME}_{\text {Total }}$, there is no difference between pre-service and in-service teachers ( $t$-value -.021, $p$ <.983). However, when the factors of ME were analyzed, one factor Community Relations (MECR) is significantly different between the two types of teachers based on education level in which pre-service teachers were better than in-service teachers ( $t$-value $-2.108, p<.037)$ and for Curriculum Instruction (MECI) based on gender $(\mathrm{p}<.005)$ in which female in-service teachers had better scores.

Pearson Product-Moment Correlation Coefficient between EP and ME (total and factors) based on Education Level (EL), Teaching Assignment (TA), and Gender

As shown in Table 3, the English proficiency (EP Total) is not correlated with multicultural education $\left(\mathrm{ME}_{\text {Total }}\right)$. However, when the $\mathrm{EP}_{\text {Total }}$ is correlated with one aspect of $\mathrm{ME}$, it is found that pre-service teachers' $\mathrm{EP}_{\text {Total }}$ is related to ME: School Leadership $(\mathrm{r}=-.230, p<.029)$ and ME: General Sensitivity $(\mathrm{r}$ $=.214, p<.042$ ). See discussion. 
Table 1

Summary of Mean, Standard Deviation and Significant Level between Pre-service and In-service Teachers' English

Proficiency Total and Its Skills and Aspects based on Teaching Assignment Level, Education Level, and Gender

\begin{tabular}{|c|c|c|c|c|c|c|c|c|c|c|c|c|c|}
\hline \multirow[t]{2}{*}{ Variables } & \multicolumn{4}{|c|}{ Employability Teaching Status } & \multicolumn{5}{|c|}{$\begin{array}{c}\text { Teaching Assignment Level and Education } \\
\text { Level }\end{array}$} & \multicolumn{4}{|c|}{ Gender } \\
\hline & Category & Mean & SD & Sig. & Category & $\mathbf{N}$ & $\begin{array}{l}\text { Level } \\
\text { Mean }\end{array}$ & SD & Sig. & Category & Mean & SD & Sig. \\
\hline \multirow{10}{*}{$\begin{array}{c}\text { English } \\
\text { Proficiency }\end{array}$} & \multirow{5}{*}{$\begin{array}{c}\text { Pre-service } \\
\quad(\mathrm{n}=90)\end{array}$} & \multirow[t]{5}{*}{480} & \multirow[t]{5}{*}{41.07} & \multirow[t]{10}{*}{.000} & PS-Und & 14 & 482 & 39.32 & .654 & \multirow{5}{*}{$\begin{array}{c}\text { Male } \\
(n=18)\end{array}$} & \multirow[t]{5}{*}{489} & \multirow[t]{5}{*}{39.56} & \\
\hline & & & & & PS-Grad & 1 & 463 & - & & & & & \\
\hline & & & & & JHS-Und & 30 & 494 & 42.43 & .082 & & & & \\
\hline & & & & & JHS-Grad & 3 & 539 & 1.73 & & & & & .835 \\
\hline & & & & & SHS-Und & 27 & 468 & 40.17 & .040 & & & & 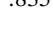 \\
\hline & \multirow{5}{*}{$\begin{array}{l}\text { In-service } \\
\quad(n=14)\end{array}$} & \multirow[t]{5}{*}{528} & \multirow[t]{5}{*}{42.59} & & SHS-Grad & 6 & 506 & 36.27 & & \multirow{5}{*}{$\begin{array}{l}\text { Female } \\
(n=86)\end{array}$} & \multirow[t]{5}{*}{486} & \multirow[t]{5}{*}{45.37} & \\
\hline & & & & & HE-Und & 9 & 493 & 27.50 & .001 & & & & \\
\hline & & & & & HE-Grad & 4 & 569 & 30.25 & & & & & \\
\hline & & & & & MD-Und & 10 & 459 & 38.45 & & & & & \\
\hline & & & & & MD-Grad & 0 & - & - & - & & & & \\
\hline \multirow[t]{10}{*}{ Listening } & \multirow{5}{*}{$\begin{array}{c}\text { Pre-service } \\
\quad(\mathrm{n}=90)\end{array}$} & \multirow[t]{5}{*}{46} & 4.56 & .000 & PS-Und & 14 & 46 & 4.34 & .815 & Male & 47 & 5.00 & \\
\hline & & & & & PS-Grad & 1 & 45 & - & & $(n=18)$ & & & \\
\hline & & & & & JHS-Und & 30 & 47 & 4.79 & .376 & & & & \\
\hline & & & & & JHS-Grad & 3 & 50 & 2.00 & & & & & 650 \\
\hline & & & & & SHS-Und & 27 & 44 & 4.66 & .040 & & & & \\
\hline & In-service & 51 & 4.95 & & SHS-Grad & 6 & 49 & 2.34 & & Female & 47 & 4.90 & \\
\hline & $(\mathrm{n}=14)$ & & & & HE-Und & 9 & 48 & 2.89 & .001 & $(\mathrm{n}=86)$ & & & \\
\hline & & & & & HE-Grad & 4 & 57 & 4.76 & & & & & \\
\hline & & & & & MD-Und & 10 & 45 & 3.86 & & & & & \\
\hline & & & & & MD-Grad & 0 & - & - & - & & & & \\
\hline Structure & Pre-service & 47 & 5.69 & .001 & PS-Und & 14 & 49 & 5.08 & .957 & Male & 47 & 5.48 & \\
\hline & $(\mathrm{n}=90)$ & & & & PS-Grad & 1 & 49 & - & & $(n=18)$ & & & \\
\hline & & & & & JHS-Und & 30 & 49 & 6.21 & .229 & & & & \\
\hline & & & & & JHS-Grad & 3 & 53 & 4.04 & & & & & .570 \\
\hline & & & & & SHS-Und & 27 & 46 & 4.90 & .160 & & & & \\
\hline & In-service & 53 & 6.13 & & SHS-Grad & 6 & 49 & 5.28 & & Female & 48 & 6.16 & \\
\hline & $(n=14)$ & & & & HE-Und & 9 & 48 & 6.02 & .008 & $(\mathrm{n}=86)$ & & & \\
\hline & & & & & HE-Grad & 4 & 59 & 4.57 & & & & & \\
\hline & & & & & MD-Und & 10 & 44 & 5.66 & & & & & \\
\hline & & & & & MD-Grad & 0 & - & - & - & & & & \\
\hline Reading & Pre-service & 50 & 4.03 & .273 & PS-Und & 14 & 50 & 4.12 & .282 & Male & 51 & 2.85 & \\
\hline & $(\mathrm{n}=90)$ & & & & PS-Grad & 1 & 45 & - & & $(\mathrm{n}=18)$ & & & \\
\hline & & & & & JHS-Und & 30 & 52 & 3.43 & .821 & & & & \\
\hline & & & & & JHS-Grad & 3 & 52 & 2.51 & & & & & .575 \\
\hline & & & & & SHS-Und & 27 & 50 & 4.71 & .686 & & & & \\
\hline & In-service & 52 & 3.22 & & SHS-Grad & 6 & 50 & 2.34 & & Female & 50 & 4.14 & \\
\hline & $(n=14)$ & & & & HE-Und & 9 & 51 & 2.55 & .057 & $(\mathrm{n}=86)$ & & & \\
\hline & & & & & HE-Grad & 4 & 55 & 1.92 & & & & & \\
\hline & & & & & MD-Und & 10 & 48 & 3.50 & & & & & \\
\hline & & & & & MD-Grad & 0 & - & - & - & & & & \\
\hline
\end{tabular}

Notes:

\begin{tabular}{|c|c|c|c|}
\hline $\begin{array}{l}\text { PS: Primary School } \\
\text { JHS. Junior High School }\end{array}$ & - HE: Higher Education & - Und: Undergraduates & - Grad: Graduates \\
\hline : Junior High School & HS: Senior High School & sing Data & \\
\hline
\end{tabular}

Table 2

Summary of Mean, Standard Deviation and Significant Level between Pre-service and In-service Teachers' Multicultural Education Total and Its Subsets based on Teaching Assignment Level, Education Level, and Gender

\begin{tabular}{|c|c|c|c|c|c|c|c|c|c|c|c|c|c|}
\hline \multirow[t]{2}{*}{ Variables } & \multicolumn{4}{|c|}{ Teaching Status } & \multicolumn{5}{|c|}{ Teaching Assignment Level and Education Level } & \multicolumn{4}{|c|}{ Gender } \\
\hline & Category & Mean & SD & Sig. & Category & $\mathrm{n}$ & Mean & SD & Sig. & Category & Mean & SD & Sig. \\
\hline \multirow[t]{10}{*}{ ME } & Preservice & 177 & 24.69 & .983 & PS-Und & 14 & 178 & 20.97 & & Male & 184 & 21.93 & .130 \\
\hline & $(n=90)$ & & & & PS-Grad & 1 & 184 & - & .801 & $(n=18)$ & & & \\
\hline & & & & & JHS- Und & 30 & 175 & 24.54 & .472 & & & & \\
\hline & & & & & JHS-Grad & 3 & 186 & 26.10 & & & & & \\
\hline & & & & & SHS-Und & 27 & 173 & 25.09 & .591 & & & & \\
\hline & In-service & 177 & 16.69 & & SHS-Grad & 6 & 179 & 11.94 & & Female & 175 & 23.86 & \\
\hline & $(n=14)$ & & & & HE-Und & 9 & 178 & 30.89 & .392 & $(\mathrm{n}=86)$ & & & \\
\hline & & & & & HE-Grad & 4 & 163 & 12.28 & & & & & \\
\hline & & & & & MD-Und & 10 & - & - & & & & & \\
\hline & & & & & MD-Grad & 0 & - & - & - & & & & \\
\hline \multirow[t]{10}{*}{ MEPD } & Pre-service & 3.6 & 0.6 & .421 & PS-Und & 14 & 3.7 & 0.64 & .815 & Male & 3.6 & 0.50 & .670 \\
\hline & $(n=90)$ & & & & PS-Grad & 1 & 3.9 & - & & $(n=18)$ & & & \\
\hline & & & & & JHS-Und & 30 & 3.5 & 0.59 & .466 & & & & \\
\hline & & & & & JHS-Grad & 3 & 3.2 & 0.72 & & & & & \\
\hline & & & & & SHS-Und & 27 & 3.5 & 0.56 & .503 & & & & \\
\hline & In-service & 3.4 & 0.47 & & SHS-Grad & 6 & 3.7 & 0.32 & & Female & 3.5 & 0.60 & \\
\hline & $(n=14)$ & & & & HE-Und & 9 & 3.4 & 0.75 & .362 & $(\mathrm{n}=86)$ & & & \\
\hline & & & & & HE-Grad & 4 & 3.1 & 0.13 & & & & & \\
\hline & & & & & MD-Und & 10 & - & - & & & & & \\
\hline & & & & & MD-Grad & 0 & - & - & - & & & & \\
\hline
\end{tabular}




\begin{tabular}{|c|c|c|c|c|c|c|c|c|c|c|c|c|c|}
\hline \multirow[t]{10}{*}{ MECI } & \multirow{5}{*}{$\begin{array}{l}\text { Pre-service } \\
\quad(\mathrm{n}=90)\end{array}$} & \multirow[t]{5}{*}{3.5} & \multirow[t]{5}{*}{0.59} & \multirow[t]{10}{*}{.238} & PS-Und & 14 & 3.4 & 0.72 & .822 & \multirow{5}{*}{$\begin{array}{c}\text { Male } \\
(\mathrm{n}=18)\end{array}$} & \multirow[t]{5}{*}{3.8} & \multirow[t]{5}{*}{0.46} & \multirow[t]{10}{*}{.005} \\
\hline & & & & & PS-Grad & 1 & 3.6 & - & & & & & \\
\hline & & & & & JHS-Und & 30 & 3.4 & 0.52 & .119 & & & & \\
\hline & & & & & JHS-Grad & 3 & 3.9 & 0.51 & & & & & \\
\hline & & & & & SHS-Und & 27 & 3.4 & 0.61 & .205 & & & & \\
\hline & \multirow{5}{*}{$\begin{array}{c}\text { In-service } \\
(\mathrm{n}=14)\end{array}$} & \multirow[t]{5}{*}{3.7} & \multirow[t]{5}{*}{0.37} & & SHS-Grad & 6 & 3.7 & 0.32 & & & 3.4 & 0.57 & \\
\hline & & & & & HE-Und & 9 & 3.7 & 0.70 & .457 & $(\mathrm{n}=86)$ & & & \\
\hline & & & & & HE-Grad & 4 & 3.4 & 0.22 & & & & & \\
\hline & & & & & MD-Und & 10 & - & - & & & & & \\
\hline & & & & & MD-Grad & 0 & - & - & - & & & & \\
\hline MESL & Pre-service & 3.6 & 0.86 & .559 & PS-Und & 14 & 3.6 & 0.74 & .956 & Male & 3.7 & 0.88 & .396 \\
\hline & $(\mathrm{n}=90)$ & & & & PS-Grad & 1 & 3.6 & - & & $(n=18)$ & & & \\
\hline & & & & & JHS-Und & 30 & 3.5 & 0.81 & .224 & & & & \\
\hline & & & & & JHS-Grad & 3 & 4.1 & 0.46 & & & & & \\
\hline & & & & & SHS-Und & 27 & 3.6 & 0.92 & .837 & & & & \\
\hline & In-service & 3.7 & 0.54 & & SHS-Grad & 6 & 3.7 & 0.55 & & Female & 3.6 & 0.81 & \\
\hline & $(\mathrm{n}=14)$ & & & & HE-Und & 9 & 3.6 & 1.27 & .892 & $(\mathrm{n}=86)$ & & & \\
\hline & & & & & HE-Grad & 4 & 3.6 & 0.66 & & & & & \\
\hline & & & & & MD-Und & 10 & - & - & & & & & \\
\hline & & & & & MD-Grad & 0 & - & - & - & & & & \\
\hline MECR & Pre-service & 2.7 & 0.64 & .037 & PS-Und & 14 & 2.6 & 0.72 & .592 & Male & 2.9 & 0.60 & .157 \\
\hline & $(\mathrm{n}=90)$ & & & & PS-Grad & 1 & 3.0 & - & & $(\mathrm{n}=18)$ & & & \\
\hline & & & & & JHS-Und & 30 & 2.7 & 0.68 & .077 & & & & \\
\hline & & & & & JHS-Grad & 3 & 3.5 & 1.08 & & & & & \\
\hline & & & & & SHS-Und & 27 & 2.6 & 0.59 & .198 & & & & \\
\hline & In-service & 3.1 & 0.61 & & SHS-Grad & 6 & 3.0 & 0.47 & & Female & 2.7 & 0.65 & \\
\hline & $(\mathrm{n}=14)$ & & & & HE-Und & 9 & 2.8 & 0.65 & .723 & $(n=86)$ & & & \\
\hline & & & & & HE-Grad & 4 & 2.9 & 0.54 & & & & & \\
\hline & & & & & MD-Und & 10 & - & - & & & & & \\
\hline & & & & & MD-Grad & 0 & - & - & - & & & & \\
\hline MEGA & Pre-service & 3.9 & 0.65 & .641 & PS-Und & 14 & 4.1 & 0.54 & .349 & Male & 3.9 & 0.53 & .885 \\
\hline & $(\mathrm{n}=90)$ & & & & PS-Grad & 1 & 4.6 & - & & $(\mathrm{n}=18)$ & & & \\
\hline & & & & & JHS-Und & 30 & 4.0 & 0.70 & .666 & & & & \\
\hline & & & & & JHS-Grad & 3 & 4.1 & 0.12 & & & & & \\
\hline & & & & & SHS-Und & 27 & 3.9 & 0.64 & .573 & & & & \\
\hline & In-service & 3.9 & 0.49 & & SHS-Grad & 6 & 3.7 & 0.49 & & Female & 3.9 & 0.65 & \\
\hline & $(n=14)$ & & & & HE-Und & 9 & 3.7 & 0.57 & .974 & $(\mathrm{n}=86)$ & & & \\
\hline & & & & & HE-Grad & 4 & 3.7 & 0.53 & & & & & \\
\hline & & & & & MD-Und & 10 & - & - & & & & & \\
\hline & & & & & MD-Grad & 0 & - & - & - & & & & \\
\hline MEGS & Pre-service & 3.8 & 0.69 & .340 & PS-Und & 14 & 3.7 & 0.67 & .353 & Male & 3.9 & 0.77 & .239 \\
\hline & $(\mathrm{n}=90)$ & & & & PS-Grad & 1 & 4.4 & - & & $(\mathrm{n}=18)$ & & & \\
\hline & & & & & JHS-Und & 30 & 3.8 & 0.72 & .963 & & & & \\
\hline & & & & & JHS-Grad & 3 & 3.8 & 0.40 & & & & & \\
\hline & & & & & SHS-Und & 27 & 3.6 & 0.64 & .646 & & & & \\
\hline & In-service & 3.6 & 0.52 & & SHS-Grad & 6 & 3.5 & 0.49 & & Female & 3.7 & 0.64 & \\
\hline & $(\mathrm{n}=14)$ & & & & HE-Und & 9 & 4.0 & 0.81 & .144 & $(n=86)$ & & & \\
\hline & & & & & HE-Grad & 4 & 3.3 & 0.53 & & & & & \\
\hline & & & & & MD-Und & 10 & - & - & & & & & \\
\hline & & & & & MD-Grad & 0 & - & - & - & & & & \\
\hline MEER & Pre-service & 4.1 & 0.62 & .057 & PS-Und & 14 & 4.1 & 0.67 & .783 & Male & 4.2 & 0.50 & .441 \\
\hline & $(\mathrm{n}=90)$ & & & & PS-Grad & 1 & 4.3 & - & & $(\mathrm{n}=18)$ & & & \\
\hline & & & & & JHS-Und & 30 & 4.2 & 0.71 & .938 & & & & \\
\hline & & & & & JHS-Grad & 3 & 4.2 & 0.58 & & & & & \\
\hline & & & & & SHS-Und & 27 & 4.0 & 0.50 & .254 & & & & \\
\hline & In-service & 3.8 & 0.63 & & SHS-Grad & 6 & 3.7 & 0.70 & & Female & 4.0 & 0.65 & \\
\hline & $(\mathrm{n}=14)$ & & & & HE-Und & 9 & 4.0 & 0.61 & .111 & $(\mathrm{n}=86)$ & & & \\
\hline & & & & & HE-Grad & 4 & 3.4 & 0.48 & & & & & \\
\hline & & & & & MD-Und & 10 & - & - & & & & & \\
\hline & & & & & MD-Grad & 0 & - & - & - & & & & \\
\hline
\end{tabular}

Two aspects of ME, school leadership (MESL, $\mathrm{r}=.285, p<.007)$ and general sensitivity (MEGS, $\mathrm{r}=$ .213 , $\mathrm{p}<.044)$, are also correlated with pre-service teachers' listening skills. In contrast, in-service teachers' personal development (MEPD) does correlate significantly with structure $(\mathrm{r}=-.544$, $\mathrm{p}<.044)$ and reading $(\mathrm{r}=-.644, \mathrm{p}<.013)$.

Table 3

Pearson Product-Moment Correlation Coefficient between EP and ME (total and subsets) based on Education Level

\begin{tabular}{ccccccccccc}
\hline & & & ME & MEPD & MECI & MESL & MECR & MEGA & MEGS & MEER \\
\hline \multirow{6}{*}{ English } & All & Correlation & -.106 & $-.211^{*}$ & -.063 & -.185 & .018 & .013 & .108 & -.053 \\
Proficiency & $(\mathrm{n}=104)$ & Sig. & .284 & .031 & .524 & .061 & .857 & .898 & .275 & .594 \\
& Pre- & Correlation & -.084 & -.146 & -.116 & $-.230^{*}$ & -.059 & .053 & $.214^{*}$ & .081 \\
& $\begin{array}{c}\text { service } \\
(\mathrm{n}=90)\end{array}$ & Sig. & .429 & .169 & .276 & .029 & .578 & .620 & .042 & .449 \\
& $\begin{array}{c}\text { In- } \\
\text { service }\end{array}$ & Correlation & -.407 & $-.629^{*}$ & -.126 & -.173 & -.095 & -.149 & -.356 & -.388 \\
& Sig. & .149 & .016 & .669 & .555 & .747 & .611 & .211 & .170 \\
\hline
\end{tabular}




\begin{tabular}{|c|c|c|c|c|c|c|c|c|c|c|}
\hline \multirow{6}{*}{ Listening } & \multirow{6}{*}{$\begin{array}{c}\begin{array}{c}\text { All } \\
(\mathrm{n}=104) \\
\text { Pre- }\end{array} \\
\text { service } \\
(\mathrm{n}=90) \\
\text { In- } \\
\text { service } \\
(\mathrm{n}=14)\end{array}$} & Correlation & -.143 & $-.216^{*}$ & -.089 & $-.223^{*}$ & -.066 & -.022 & .104 & -.030 \\
\hline & & Sig. & .149 & .028 & .370 & .023 & .506 & .823 & .295 & .763 \\
\hline & & Correlation & -.135 & -.185 & -.145 & $-.285^{* *}$ & -.140 & .015 & $.213^{*}$ & .087 \\
\hline & & Sig. & .206 & .081 & .173 & .007 & .187 & .885 & .044 & .417 \\
\hline & & Correlation & -.322 & -.344 & -.096 & -.038 & -.204 & -.193 & -.406 & -.266 \\
\hline & & Sig. & .262 & .229 & .745 & .897 & .485 & .508 & .150 & .358 \\
\hline \multirow{6}{*}{ Structure } & \multirow{6}{*}{$\begin{array}{c}\text { All } \\
(\mathrm{n}=104) \\
\text { Pre- } \\
\text { service } \\
(\mathrm{n}=90) \\
\text { In- } \\
\text { service } \\
(\mathrm{n}=14)\end{array}$} & Correlation & -.074 & -.167 & -.056 & -.147 & .056 & .063 & .065 & -.038 \\
\hline & & Sig. & .454 & .091 & .571 & . 137 & .569 & .528 & .513 & .701 \\
\hline & & Correlation & -.036 & -.102 & -.078 & -.167 & .023 & .105 & .156 & .078 \\
\hline & & Sig. & .738 & .338 & .463 & .115 & .826 & .324 & .143 & .464 \\
\hline & & Correlation & -.479 & $-.544^{*}$ & -.326 & -.272 & -.223 & -.114 & -.358 & -.325 \\
\hline & & Sig. & .083 & .044 & .255 & .348 & .444 & .699 & .209 & .257 \\
\hline \multirow{6}{*}{ Reading } & \multirow{6}{*}{$\begin{array}{c}\text { All } \\
(\mathrm{n}=104) \\
\text { Pre- } \\
\text { service } \\
(\mathrm{n}=90) \\
\text { In- } \\
\text { service } \\
(\mathrm{n}=14)\end{array}$} & Correlation & -.106 & -.155 & -.087 & -.146 & -.071 & -.049 & .087 & -.040 \\
\hline & & Sig. & .285 & .116 & .380 & .139 & .474 & .624 & .380 & .689 \\
\hline & & Correlation & -.079 & -.103 & -.096 & -.160 & -.074 & -.030 & .146 & .034 \\
\hline & & Sig. & .459 & .334 & .367 & .131 & .487 & .780 & .169 & .752 \\
\hline & & Correlation & -.452 & $-.644^{*}$ & -.170 & -.060 & -.289 & -.205 & -.447 & -.475 \\
\hline & & Sig. & .104 & .013 & .561 & .839 & .316 & .482 & .109 & .086 \\
\hline
\end{tabular}

**. Correlation is significant at the 0.01 level (2-tailed).

*. Correlation is significant at the 0.05 level (2-tailed).

Table 4

Pearson Product-Moment Correlation Coefficient between EP and ME (total and subsets) based on Teaching Assignment

\begin{tabular}{|c|c|c|c|c|c|c|c|c|c|c|}
\hline & & & ME & MEPD & MECI & MESL & MECR & MEGA & MEGS & MEER \\
\hline \multirow{9}{*}{$\begin{array}{c}\text { English } \\
\text { Proficiency }\end{array}$} & PS & Correlation & -.348 & $-.551^{*}$ & -.342 & -.268 & -.191 & .348 & .055 & .025 \\
\hline & $(n=15)$ & Sig. & .223 & .041 & .231 & .355 & .513 & .223 & .851 & .933 \\
\hline & JHS & Correlation & .079 & -.150 & .154 & -.238 & .110 & .154 & $.442^{* * *}$ & .209 \\
\hline & $(n=33)$ & Sig. & .660 & .404 & .391 & .183 & .543 & .392 & .010 & .244 \\
\hline & SHS & Correlation & .016 & .150 & -.025 & -.036 & -.076 & -.020 & .044 & -.098 \\
\hline & $(n=33)$ & Sig. & .929 & .404 & .889 & .840 & .672 & .911 & .807 & .588 \\
\hline & $\mathrm{HE}$ & Correlation & -.206 & -.222 & -.118 & -.116 & .085 & .180 & -.426 & -.412 \\
\hline & $(n=13)$ & Sig. & .499 & .465 & .700 & .707 & .783 & .557 & .146 & .162 \\
\hline & $\begin{array}{c}\text { MD } \\
(n=10)\end{array}$ & $\begin{array}{c}\text { Correlation } \\
\text { Sig. }\end{array}$ & & & & & & & & \\
\hline \multirow{9}{*}{ Listening } & PS & Correlation & -.407 & -.506 & -.423 & -.360 & -.254 & .314 & -.022 & .053 \\
\hline & $(n=15)$ & Sig. & .149 & .065 & .132 & .207 & .380 & .275 & .940 & .859 \\
\hline & JHS & Correlation & .008 & -.157 & .060 & -.339 & -.050 & .125 & $.482^{* * *}$ & .222 \\
\hline & $(n=33)$ & Sig. & .963 & .382 & .739 & .054 & .782 & .489 & .004 & .213 \\
\hline & SHS & Correlation & -.085 & .051 & -.122 & -.087 & -.130 & -.080 & -.032 & -.107 \\
\hline & $(n=33)$ & Sig. & .638 & .777 & .498 & .631 & .471 & .659 & .862 & .552 \\
\hline & $\mathrm{HE}$ & Correlation & -.281 & -.270 & -.066 & -.228 & -.060 & -.144 & -.376 & -.382 \\
\hline & $(n=13)$ & Sig. & .353 & .371 & .830 & .453 & .846 & .638 & .205 & .198 \\
\hline & $\begin{array}{c}\text { MD } \\
(n=10)\end{array}$ & $\begin{array}{c}\text { Correlation } \\
\text { Sig. }\end{array}$ & & & & & & & & \\
\hline \multirow{9}{*}{ Structure } & PS & Correlation & -.009 & -.391 & -.002 & -.173 & .140 & $.636^{*}$ & .372 & .075 \\
\hline & $(n=15)$ & Sig. & .976 & .166 & .994 & .554 & .633 & .015 & .191 & .799 \\
\hline & JHS & Correlation & .084 & -.098 & .101 & -.177 & .076 & .153 & $.367^{*}$ & .255 \\
\hline & $(n=33)$ & Sig. & .641 & .587 & .575 & .325 & .673 & .396 & .036 & .153 \\
\hline & SHS & Correlation & .071 & .208 & -.016 & .059 & -.029 & -.007 & .017 & -.018 \\
\hline & $(n=33)$ & Sig. & .694 & .246 & .928 & .744 & .873 & .969 & .926 & .919 \\
\hline & $\mathrm{HE}$ & Correlation & -.190 & -.226 & -.177 & -.092 & .172 & .360 & -.469 & -.400 \\
\hline & $(n=13)$ & Sig. & .535 & .457 & .564 & .764 & .575 & .227 & .106 & .175 \\
\hline & $\begin{array}{c}\text { MD } \\
(n=10)\end{array}$ & $\begin{array}{c}\text { Correlation } \\
\text { Sig. }\end{array}$ & & & & & & & & \\
\hline \multirow{9}{*}{ Reading } & PS & Correlation & $-.566^{*}$ & $-.570^{*}$ & $-.547^{*}$ & -.203 & -.453 & -.104 & -.287 & -.051 \\
\hline & $(n=15)$ & Sig. & .035 & .033 & .043 & .486 & .104 & .723 & .320 & .862 \\
\hline & JHS & Correlation & -.048 & -.161 & .043 & -.328 & .030 & .088 & .225 & -.036 \\
\hline & $(n=33)$ & Sig. & .790 & .370 & .812 & .063 & .868 & .626 & .209 & .841 \\
\hline & SHS & Correlation & .075 & .211 & .065 & -.005 & -.153 & -.019 & .077 & .053 \\
\hline & $(n=33)$ & Sig. & .678 & .237 & .721 & .978 & .395 & .918 & .669 & .770 \\
\hline & $\mathrm{HE}$ & Correlation & .055 & .054 & .028 & .138 & .089 & .192 & -.091 & -.195 \\
\hline & $(n=13)$ & Sig. & .858 & .860 & .926 & .652 & .772 & .531 & .769 & .524 \\
\hline & $\begin{array}{c}\text { MD } \\
(n=10)\end{array}$ & $\begin{array}{c}\text { Correlation } \\
\text { Sig. }\end{array}$ & & & & & & & & \\
\hline
\end{tabular}


Table 5

Pearson Product-Moment Correlation Coefficient between EP and ME (total and subsets) based on Gender

\begin{tabular}{ccccccccccc}
\hline & & & ME & MEPD & MECI & MESL & MECR & MEGA & MEGS & MEER \\
\hline \multirow{3}{*}{ English } & Male & Correlation & .056 & .055 & .267 & -.204 & .271 & -.044 & -.070 & -.156 \\
Proficiency & $(\mathrm{n}=18)$ & Sig. & .826 & .828 & .284 & .417 & .277 & .862 & .782 & .538 \\
& Female & Correlation & -.137 & $-.251^{*}$ & -.120 & -.185 & -.026 & .021 & .144 & -.041 \\
& $(\mathrm{n}=86)$ & Sig. & .208 & .020 & .273 & .089 & .809 & .846 & .184 & .707 \\
\hline \multirow{5}{*}{ Listening } & Male & Correlation & -.089 & -.082 & .190 & -.321 & .038 & -.193 & -.050 & -.235 \\
& $(\mathrm{n}=18)$ & Sig. & .724 & .746 & .449 & .194 & .881 & .442 & .843 & .348 \\
& Female & Correlation & -.163 & $-.242^{*}$ & -.155 & -.207 & -.094 & .007 & .136 & -.002 \\
& $(\mathrm{n}=86)$ & Sig. & .134 & .025 & .155 & .056 & .388 & .949 & .211 & .985 \\
\hline \multirow{5}{*}{ Structure } & Male & Correlation & -.034 & .088 & .042 & -.301 & .195 & -.070 & -.144 & -.160 \\
& $(\mathrm{n}=18)$ & Sig. & .893 & .729 & .868 & .225 & .438 & .781 & .568 & .526 \\
& Female & Correlation & -.072 & -.202 & -.055 & -.113 & .043 & .081 & .119 & -.017 \\
& $(\mathrm{n}=86)$ & Sig. & .510 & .062 & .616 & .301 & .691 & .457 & .275 & .878 \\
\hline \multirow{5}{*}{ Reading } & Male & Correlation & .138 & .211 & .307 & .040 & -.091 & .162 & -.027 & -.105 \\
& $(\mathrm{n}=18)$ & Sig. & .585 & .402 & .216 & .875 & .720 & .520 & .916 & .677 \\
& Female & Correlation & -.148 & -.200 & -.153 & -.182 & -.079 & -.072 & .101 & -.038 \\
& $(\mathrm{n}=86)$ & Sig. & .173 & .064 & .160 & .093 & .471 & .513 & .356 & .730 \\
\hline
\end{tabular}

**. Correlation is significant at the 0.01 level (2-tailed).

*. Correlation is significant at the 0.05 level (2-tailed).

Table 6

Pearson Product-Moment Correlation Coefficient among EP+EL+TA + Gender and ME (Total and Subsets)

\begin{tabular}{|c|c|c|c|c|c|c|c|c|c|}
\hline & & ME & MEPD & MECI & MESL & MECR & MEGA & MEGS & MEER \\
\hline $\begin{array}{c}\text { EP+EL } \\
+\end{array}$ & $\begin{array}{l}\text { Pearson } \\
\text { Correlation }\end{array}$ & -.111 & $-.215^{*}$ & -.065 & -.185 & .018 & .006 & .103 & -.060 \\
\hline $\begin{array}{c}\text { TA+Ge } \\
\text { nder }\end{array}$ & Sig. (2-tailed) & .264 & .028 & .511 & .061 & .857 & .956 & .297 & .546 \\
\hline
\end{tabular}

**. Correlation is significant at the 0.01 level (2-tailed).

*. Correlation is significant at the 0.05 level (2-tailed).

\section{Regression analyses}

Based on the correlations obtained above, the result of stepwise regression analyses shows that among other factors of English proficiency only listening contributes to teachers' personal development (MEPD) and their school leadership (MESL). The contribution of listening to MEPD is 4.6 per cent and to MESL is 5 per cent.

When the three aspects of English proficiency are combined to predict subsets of ME, it is shown that two of them, MESL and MEGS, are correlated with pre-service teachers' listening and only MEPD is correlated with in-service teachers' Structure $(\mathrm{r}=.544 ; p<.044)$ and reading $(\mathrm{r}=.644 ; p<.013)$ of inservice teachers. However, using multiple regression stepwise, only reading appears to contribute significantly to the MEPD with the $\mathrm{R}=.644, \mathrm{R}^{2}=.415$ and level of F-significance $p<.013$.

Lastly, when all predictors $(\mathrm{EP}+\mathrm{EL}+\mathrm{TA}+$ Gender) are combined for ME subsets $(\mathrm{N}=104)$, only MEPD is influenced by them significantly $(\mathrm{R}=.215$, $\left.\mathrm{R}^{2}=.046, \mathrm{p}<.028\right)$.

\section{DISCUSSION}

Being a certified teacher is a big deal for most of the English teachers nowadays. However, two of the prerequisites for this status must be fulfilled due to some requirements of living in the 21 st century; for example: they have to have high English proficiency as measured by TOEFL score (The George Washington University, 2013) and by fetching the dream of having "one world, many peoples" on many occasions, to borrow Babaii's (2018) term. The preservice teachers in this study assumed that once they were legally becoming in-service, they could lead the school better and have enough sensitivity to their students' background. This is in line with the results of the previous studies done by Futrell, Gomez, \& Bedden (2003) and Gorski (2006) that having wellrounded multicultural knowledge is vital for student teachers' attentiveness, preparedness, and mindsets concerning students of diverse backgrounds they will eventually teach. In other words, by possessing skills and knowledge in multicultural pedagogy, preservice teachers will be empowered to work towards creating structures and social arrangements in school environments that promote equal opportunities in education for all students in school and out of school, without any discrimination on the basis of race, ethnic, language, belief, sex, culture, and social status (see Banks, 2001a, 2001b; Yilmaz, 2016).

On the other hand, for in-service teachers, their total EP's significant correlation with their personal development (MEPD) shows that with their ability in English they have developed talent and potential in their teaching and learning activities. The stronger the teachers' English proficiency score, the higher their personal development (which is one aspect of multicultural education of this study), to solve the 
problem in their EFL teaching and learning process. This is possible because, by being proficient in English, these teachers can participate in international academic communities that will facilitate their global education and academic success (Focho, 2011; Jenkins, 2006). Importantly, their
English ability would enable them to access numerous scientific publications in such related fields as English and language teaching, participate in online communication, and benefit from technological transfer (Graddol, 2000).

Table 7

Summary Statistics for Multiple Regressions Analyses between EP (Total and Factors) and ME (Total and Subsets)

\begin{tabular}{|c|c|c|c|c|c|c|c|c|}
\hline Category & Model & $\begin{array}{c}\text { Dependent } \\
\text { Variable }\end{array}$ & Predictor & $\mathbf{R}$ & $\mathbf{R}^{2}$ & Df & $\mathbf{F}$ & Sig. F \\
\hline \multirow{9}{*}{$\begin{array}{l}\text { Education } \\
\text { Level }\end{array}$} & \multirow{3}{*}{$\begin{array}{c}\text { All } \\
(\mathrm{n}=104)\end{array}$} & \multirow{2}{*}{ MEPD } & $\mathrm{EP}_{\text {Total }}$ & .211 & .045 & 1 & 4.761 & .031 \\
\hline & & & \multirow{2}{*}{ Listening } & .216 & .047 & 1 & 4.982 & .028 \\
\hline & & MESL & & .223 & .050 & 1 & 5.316 & .023 \\
\hline & \multirow{4}{*}{$\begin{array}{c}\text { Pre- } \\
\text { service } \\
(\mathrm{N}=90)\end{array}$} & \multirow{2}{*}{ MESL } & $\mathrm{EP}_{\text {Total }}$ & .230 & .053 & 1 & 4.901 & .029 \\
\hline & & & Listening & .285 & .081 & 1 & 7.752 & .007 \\
\hline & & \multirow{2}{*}{ MEGS } & $\mathrm{EP}_{\text {Total }}$ & .214 & .046 & 1 & 4.240 & .042 \\
\hline & & & Listening & .213 & .045 & 1 & 4.189 & .044 \\
\hline & \multirow{2}{*}{$\begin{array}{c}\text { In-service } \\
(\mathrm{N}=14)\end{array}$} & \multirow{2}{*}{ MEPD } & $\mathrm{EP}_{\text {Total }}$ & .629 & .395 & 1 & 7.841 & .016 \\
\hline & & & Reading & .644 & .415 & 1 & 8.522 & .013 \\
\hline \multirow{7}{*}{$\begin{array}{c}\text { Teaching } \\
\text { Assignment }\end{array}$} & \multirow{5}{*}{$\begin{array}{c}\text { Primary } \\
\text { School } \\
(\mathrm{N}=15)\end{array}$} & ME & Reading & .566 & .321 & 1 & 5.664 & .035 \\
\hline & & \multirow{2}{*}{ MEPD } & $\mathrm{EP}_{\text {Total }}$ & .551 & .304 & 1 & 5.241 & .041 \\
\hline & & & Reading & .570 & .325 & 1 & 5.788 & .033 \\
\hline & & MECI & Reading & .547 & .299 & 1 & 5.110 & .043 \\
\hline & & MEGA & Structure & .636 & .404 & 1 & 8.147 & .015 \\
\hline & \multirow{2}{*}{$\begin{array}{c}\text { JHS } \\
(\mathrm{N}=33)\end{array}$} & \multirow{2}{*}{ MEGS } & $\mathrm{EP}_{\text {Total }}$ & .442 & .196 & 1 & 7.545 & .010 \\
\hline & & & Listening & .482 & .233 & 1 & 9.404 & .004 \\
\hline \multirow{2}{*}{ Gender } & Female & \multirow{2}{*}{ MEPD } & $\mathrm{EP}_{\text {Total }}$ & .251 & .063 & 1 & 5.651 & .020 \\
\hline & $(\mathrm{N}=86)$ & & Listening & .242 & .058 & 1 & 5.219 & .025 \\
\hline All Variables & $\mathrm{N}=104$ & MEPD & $\mathrm{EP}+\mathrm{EL}+\mathrm{TA}+\mathrm{Gender}$ & .215 & .046 & 1 & 4.959 & .028 \\
\hline
\end{tabular}

That the school leadership and general sensitivity are also correlated with pre-service teachers' listening skills and in-service teachers' personal development is correlated significantly with structure and reading can be interpreted that by having the highest EP score, the pre-service teachers were confident that they would become an effective school leader and more culturally-responsive educator once starting their actual teaching appointment. On the other hand, in-service teachers thought that with their ability in English they have developed talent and potential in their teaching and learning activities. The higher the English proficiency score, the higher the teachers' personal development, self-awareness, self-knowledge and the ability to solve the problem in their EFL teaching and learning process.

Furthermore, that in-service teachers' listening ability $_{\text {Total }}$ is correlated with their personal development and to their leadership in school probably happens because a characteristic of good leaders is being able to listen to their significant others, in this case their students, parents and professional colleagues. It is assumed that by having good listening skills, teachers are able to apply their talents to their own personal development. Teachers with good comprehension in listening could have better understanding of the environment surrounding them. They can develop their potential in school leadership, manage the class and conduct the learning and teaching process to achieve their students' goals.

That the contribution of listening to personal development is low and only 4.6 per cent and to school leadership is 5 per cent is possibly caused by teachers not yet having much experience listening to English conversations, lectures, or any other listening sources in English.

\section{CONCLUSION}

The main conclusion drawn from this study is related to teachers' growth in the ownership of English proficiency and multicultural education awareness and sensitivity. There is little evidence for a definite answer at this stage. Although the degree of significant relationships and additions to the explained variation for teachers' multicultural education found was not very strong, a positive attitude combined with knowledge of cultural diversity should be encouraged among EFL teachers so they can adjust their teaching practices to their students' backgrounds. The second important conclusion is that although multicultural education is important in any culture, the manner in which it is practiced will likely differ from culture to culture due 
to variations in societal make up and cultural values and emphases.

\section{IMPLICATIONS}

The literature review revealed that pre-service and inservice EFL teachers need to develop a good command of English. In addition, they need to have a broad knowledge of other cultures to be able to perform effectively in today's multicultural classrooms. Since this research supports the importance of having higher English proficiency as well as multiculturalism, it is humane if individual EFL teachers have their interests in other cultures, languages, and identities in addition to their own. Therefore, they must be exposed to various cultures for having intercultural communication skills and education to live in this era. Also, relevant institutions must support and take these ideals into account by investigating tolerant heterogeneous communities.

Similar studies in the future should be conducted by: (1) using more extensive population and more precise instruments; (2) incorporating perceptions of significant others, such as students and school principals; and (3) trying out multicultural programs in teacher education by taking a group of student teachers and giving them special exposure to multicultural content integrated into their methods of teaching EFL literacy course with follow-ups after their actual teaching service.

\section{REFERENCES}

American Association of School Librarians (AASL). (2007). Standard for the 21st century learner. AASL.

APJII. (2014). DNS Nawala performance report. http://www.apii.or.id/v2/read/page/halamandata/9statistick.html

Babaii, E. (2018). Multiculturalism: An asset or a problem? Implications for intercultural education. Intercultural Communication Education, 1(2), 45-53. https://doi.org/10.29140/ice.v1n2.65

Baker, W. (2003). Should culture be an overt component of EFL instruction outside of English-speaking countries? Asian EFL Journal, 5(4), 1-25. http://www.asian-efljournal.com/dec_03_wb.pdf

Banks, J. A. (1986). Multicultural education: Development, paradigms and goals. In J. A. Banks \& J. Lynch (Eds.), Multicultural education in western societies (pp. 2 -28). Prager.

Banks, J. A. (2001a). Multicultural education: Goals, possibilities and challenges. In C. F. Diaz (Ed.), Multicultural education in the 21st century (pp. 11-22). Addison-Wesley.
Banks, J. A. (2001b). History, characteristics and goals. In J. A. Banks \& C. A. M. Banks (Eds.), Handbook of research on multicultural education (pp. 3-29). Wiley.

Baptiste, H. P., Jr. (1986). Multicultural education and urban schools from a sociohistorical perspective: Internalizing multiculturalism. Journal of Educational Equity and Leadership, 6, 295 - 312. https://doi.org/10.1177\%2F004208599703200 1007

Berliner, D. C. (1986). A status report on the study of teacher effectiveness. Journal of Research in Science, 13, $369-382$. https://doi.org/10.1002/tea.3660130415

Berliner, D. C., \& Cassanova, U. (1986). Does culture affect reading comprehension? Instructor, 95/96, 28-29. https://doi.org/10.1002/tea.3660130415

Bjorn, F., Stein, K., \& Fathul, W. (2005). Information dissemination in a developing society: Internet cafe users in Indonesia. The Electronic Journal of Information System in Developing Countries, 22(3), 1-16. https://doi.org/10.1002/j.16814835.2005.tb00141.x

Brent, A. (1982). Multicultural education and relativism: A reply to Phillips-Bell. Journal of Philosophy of Education, 16, 125 - 130. https://doi.org/10.1111/j.14679752.1982.tb00604.x

British Council. (2013). Languages for the future. http://www.britishcouncil.org/sites/britishcoun cil.uk2/files/languages-for-the-futurereport.pdf

Campbell, R. L., \& Farrell, R. V. (1985). The identification of competencies for multicultural teacher education. Negro Educational Review, $36,137-44$.

Chavers, D. (1979). The revolution in Indian education.[Paper presentation] The annual symposium on the American Indian, Northeastern Oklahoma State University.

Cloud, N., Genesee, F., \& Hamayan, E. (2009). Literacy instruction for English language learners. A teacher's guide to research-based practices. Heinemann.

Coleman, H. (2010). Developing countries and the English language: Rhetoric, risks, roles and recommendations. http://www.teachingenglish.org.uk/sites/teache ng/files/Z413\%20EDB\%20Section01_0.pdf

Colombo, E. (2015). Multiculturalism: An overview of multicultural debates in western societies. Current Sociology Review, 63(6), 800-824. https://doi.org/10.1177/0011392115586802

Crystal, D. (2003). English as a global language (2nd ed.). Cambridge University press. https://doi.org/10.1017/CBO9780511486999 
Dickson, P., \& Cumming, A. (1996). Profiles of language education in 25 countries. National Foundation for Educational Research. https://www.nfer.ac.uk/publications/91128/911 28.pdf

Diem, C. D. (2012). How the presence of a technologically supported library influences high school students reading habits and skills. Global Advanced Research Journal of Library, Information and Archival Studies, 1(1), 001005. http://garj.org/full-articles/how-thepresence-of-a-technologically-supportedlibrary-influences-high-school-studentsreading-habits-and-skills.pdf?view=inline

Diem, C. D., \& Novitasari, R. (2012). Exploring online resources for/with fifth graders to cultivate reading habits and increase English literacy achievement. Basic Research Journal of Education Research and Review, 1(3), 3847. http://repository.unsri.ac.id/id/eprint/16452

Education First English Proficiency Index (EF EPI). (2012). EF English Proficiency Index 2012. http://www.ef.co.id/_/ //media/efcom/epi/201 2/full_reports/ef-epi-2012-report-masterlr-2

Fleras, A., \& Elliott, J. L. (2002). Engaging diversity: Multiculturalism in Canada (2nd ed.). Nelson Thomson Learning.

Focho, G. N. (2011). Student perceptions of English as a developmental tool in Cameroon. http://www.teachingenglish.org.uk/sites/teache ng/files /Z413\%20EDB\%20Section07pdf

Fowers, B. J., \& Davidov, B. J. (2006). The virtue of multiculturalism: Personal transformation, character, and openness to the other. American Psychologist, 61, 581-594. http://dx.doi.org/10.1037/0003-066X.61.6.581

Futrell, M. H., Gomez, J., \& Bedden, D. (2003). Teaching the children of a new America: The challenge of diversity. Phi Delta Kappan,84(5), 381-385. https://doi.org/10.1177/003172170308400512

George Washington University (2013). Paper-based TOEFL. The George Washington University.

Geske, A., \& Ozola, A. (2008). Factors influencing reading literacy at primary school level. Problems of Education in the $21^{\text {st }}$ Century, 6, 71-77. http://oaji.net/articles/2014/4571392233338.pdf

Gollnick, D. M., \& Chinn, P. C. (1986). Multicultural education in a pluralistic society (2nd ed.). Charles E. Merrill Publishing Company.

Good, T. I., \& Brophy, J. E. (1987). Looking in classroom (4th ed.). Harper and Row Publishers.

Gorski, P. C. (2006). Complicity with conservatism: The depoliticizing of multicultural and intercultural education. Intercultural Education, 17(2), 163-177. https://doi.org/10.1080/14675980600693830
Graddol, D. (2000). The future of English? A guide to forecasting the popularity of the English language in the 21st century. The British Council.

Guo, Y. (2011). Perspectives of immigrant Muslim parents: Advocating for religious diversity in Canadian schools. Multicultural Education, 18, 55-60. https://files.eric.ed.gov/fulltext/EJ951848.pdf

Hill, S. (2006-2008). Developing early literacy: Assessment and teaching. Eleanor Curtain Publishing.

Jenkins, J. (2006). Current perspectives on teaching world Englishes and English as a lingua franca. TESOL Quarterly, 36(3), 265-274. https://doi.org/10.2307/40264515

Jensen, A. R. (1980). Bias in mental testing. Behavioural and Brain Sciences, 3(3), 325333. https://doi.org/10.1017/S0140525X00005161

Jones-Kavalier, B. R., \& Flannigan, S. L. (2006). Connecting the digital dots: Literacy of the 21st Century. Education Quarterly, 2, 8-10. https://er.educause.edu/-/media/files/articledownloads/eqm0621.pdf

Kemendikbud. (2013). Kerangka dasar dan struktur kurikulum 2013.

http://sertifikasi.fkip.uns.ac.id/modul/1\%20Ma teri\%20KPPG\%20\&\%20Kurikulum\%202013/ STRUKTUR\%20DAN\%20ISI\%20KURIKUL UM\%202013.pdf

Lembaga Penjaminan Mutu Pendidikan (LPMP) Sumatra Selatan [Quality Assurance of South Sumatra Education[. (2012). Profil pendidik dan tenaga kependidikan. LPMP Sumatra Selatan: Seksi system informasi. Handayani Printing and Publishing.

Livingstone, S., Bober, M., \& Helsper, E. (2005). Internet literacy among children and young people: Findings from the UK children go online project. London School of Economics and Political Science.

Midwest Race Desegregation Assistance Centre. (1983). Building level assessment for multicultural and non-sexist education (Mimeograph). College of Education, Kansas State University.

Mitchell, B. M. (1985). Multicultural education: A viable component of American education? Educational Research Quarterly, 9, 7-11. https://eric.ed.gov/?id=EJ324651

Mitchelmore, M. C. (1980). Three-dimensional geometrical drawing in three cultures. Educational Studies in Mathematics, 11, 205216. https://doi.org/10.1007/BF00304356

National Council of Teachers of English. (2009). Literacy learning in the $21^{\text {st }}$ century. http://www.ncte.org/library/NCTEFiles/Resour ces/Magazine /CC0183_Brief_Literacy.pdf 
Noor, N. M. (2011). Reading habits and preferences of EFL postgraduates: A case study. Indonesian Journal of Applied Linguistics, 1(1), 1-8. https://doi.org/10.17509/ijal.v1i1.95

OECD. (2019). PISA 2018 results. What students know and can do (Vol. 1). https://www.oecd.org/

Parekh, B. (2000). Rethinking multiculturalism: Cultural diversity and political theory. Palgrave.

Purba, A. S., Malihah, E., \& Hufad, A. (2019). The implementation of multicultural education in senior high schools in Medan. BIRCI-Journal, 2(3), 226-233. https://doi.org/10.33258/birci.v2i3.411

Republic of Indonesia. (2009). Government regulation no. 74/2009, chapter II, part 1, art 3. The Republic of Indonesia.

Republic of Indonesia. (2005). The Indonesian Act of the National Education System No.14/2005, article 20. The Republic of Indonesia.

Rodriguez, F. (1981). Accreditation and teacher education: A multicultural perspective. University of Kansas.

Rohner, R. (1984). Toward a conception of culture for cross - cultural psychology. Journal of Cross - Cultural Psychology, 15, 111 - 138. https://doi.org/10.1177/0022002184015002002

Shannon-Baker, P. (2018). A multicultural education praxis: Integrating past and present, living theories, and practice. International Journal of Multicultural Education, 20(1), 4866. https://doi.org/10.18251/ijme.v20i1.1518

Shar, A. O., \& Geeslin, W. E. (1980). Children's spatial-perceptual preferences: A cross cultural comparison. Journal of Research in Multicultural Education, 11, 157-160. https://doi.org/10.2307/748908

Singh, B. R. (1984). Multicultural education: A study of the impact of the CNAA on a B.Ed. degree. Educational Studies, 10, 227-236. https://doi.org/10.1080/0305569840100303

Sunggingwati, D., \& Nguyen, H. T. M. (2013). Teachers' questioning in reading lessons: A case study in Indonesia. Electronic Journal of Foreign Language Teaching, 10(1), 80-95. https://e-

flt.nus.edu.sg/v10n12013/sunggingwati.pdf

Suparlan, P., \& Sigit, H. (1980). Culture and fertility: The case of Indonesia. The Institute of Southeast Asian Studies.

Suzuki, B. H. (1979). Multicultural education: What's it all about? Integrated Education, 17, 47-48. https://doi.org/10.1080/0020486790170109

United Nations (2013). The millennium development goals. Millennium Project.

Vancouver English Centre. (2013). English language system. http://www.vec.ca/english/1/levels.cfm

Vasquez, A. G., \& Ingle, H. T. (1982). Multicultural and minority education. In R. L. Ebel, Encyclopedia of educational research (5th ed., pp. 1267 - 1269). Macmillan Company.

Werner, E. E. (1979). Cross-cultural child development: How children influence children. Children Today, 8(2), 10-15.

Yahya, M. (2012). A study of the language difficulties of the English language centre (ELC) students at the Arab American University of Jenin. Asian Journal of Management Science and Education, 1(2), 119-130. http://www.ajmse.leenaluna.co.jp/AJMSEPDFs/Vol.1(2)/AJMSE2012 (1.2-13).pdf

Yilmaz, F. (2016). Multiculturalism and multicultural education: A case study of teacher candidates' perceptions. Cogent Education, 3, 1 - 13., https://doi.org/10.1080/2331186X.2016.11723 94

Yusfadiyah. (2010). The correlation between the teachers' performance and their pupils' achievement in English for young learners based on grade and gender [Unpublished master's thesis]. Sriwijaya University, Palembang, Indonesia. 